Research Article

\title{
The Hazardous Level of Heavy Metals in Different Medicinal Plants and Their Decoctions in Water: A Public Health Problem in Brazil
}

\author{
Paula F. S. Tschinkel, ${ }^{1}$ Elaine S. P. Melo, ${ }^{1}$ Hugo S. Pereira, ${ }^{2}$ Kassia R. N. Silva, ${ }^{2}$ \\ Daniela G. Arakaki, ${ }^{1}$ Nayara V. Lima, ${ }^{1}$ Melina R. Fernandes, ${ }^{1}$ Luana C. S. Leite, ${ }^{1}$ \\ Eliane S. P. Melo, ${ }^{1}$ Petr Melnikov, ${ }^{1}$ Paulo R. Espindola, ${ }^{1}$ Igor D. de Souza, ${ }^{1}$ \\ Valdir A. Nascimento, ${ }^{1}$ Jorge L. R. Júnior, ${ }^{2}$ Ana C. R. Geronimo, ${ }^{1}$ Francisco J. M. dos Reis, ${ }^{1}$ \\ and Valter A. Nascimento (iD)
}

${ }^{1}$ Group of Spectroscopy and Bioinformatics Applied to Biodiversity and Health, School of Medicine, Postgraduation Program in Health and Development in the Midwest Region, Faculty of Medicine, Federal University of Mato Grosso do Sul, Campo Grande, Mato Grosso do Sul, Brazil

${ }^{2}$ Institute of Chemistry of the Federal University of Mato Grosso do Sul, Campo Grande, Brazil

Correspondence should be addressed to Valter A. Nascimento; aragao60@hotmail.com

Received 5 November 2019; Revised 16 January 2020; Accepted 3 February 2020; Published 13 March 2020

Academic Editor: Stefano Curcio

Copyright (c) 2020 Paula F. S. Tschinkel et al. This is an open access article distributed under the Creative Commons Attribution License, which permits unrestricted use, distribution, and reproduction in any medium, provided the original work is properly cited.

\begin{abstract}
The determination of $\mathrm{Cd}, \mathrm{Co}, \mathrm{Cr}, \mathrm{Cu}, \mathrm{Fe}, \mathrm{Na}, \mathrm{Zn}$, and $\mathrm{Pb}$ by inductively coupled plasma-optical emission spectrometry (ICP OES) was performed on dry matter and decoctions of the medicinal plants Cordia salicifolia, Chiococca alba (L.) Hitchc., and Echites peltata used as an appetite suppressant and diuretic in Brazil. The accuracy of the measurements was analyzed by the spike recovery test. Results showed that the concentration of these seven metals $(\mathrm{Cd}, \mathrm{Co}, \mathrm{Cr}, \mathrm{Cu}, \mathrm{Fe}, \mathrm{Na}$, and $\mathrm{Zn})$ in dry plant samples is below the oral concentration of elemental impurities established by the United States Pharmacopoeia Convention (USP). However, there are no concentration limits for $\mathrm{Fe}, \mathrm{Na}$, and $\mathrm{Zn}$ established by the USP in drug substances and excipients. Levels higher than the recommended value by the USP were observed for $\mathrm{Pb}$ and the lowest for $\mathrm{Cd}, \mathrm{Co}, \mathrm{Cr}$, and $\mathrm{Cu}$, both in dried plant samples and their decoctions. In the decoctions prepared from these plants were found elements such as $\mathrm{Cd}, \mathrm{Co}, \mathrm{Cr}, \mathrm{Cu}, \mathrm{Fe}, \mathrm{Na}$, $\mathrm{Zn}$, and $\mathrm{Pb}$. In the decoction prepared from $40 \mathrm{~g}$ C. salicifolia leaves and $40 \mathrm{~g} \mathrm{C.} \mathrm{alba} \mathrm{wood,} \mathrm{the} \mathrm{content} \mathrm{of} \mathrm{Cd} \mathrm{is} \mathrm{above} \mathrm{the} \mathrm{oral} \mathrm{daily}$ exposure value set by the USP. Hazard index (HI) for decoctions prepared from these plants exceeded the threshold (1). Given the uncertainties associated with the estimates of toxicity values and exposure factors, futures researches should address the possible toxicity in humans. Uncontrolled selling and long-term ingestion of medicinal plants can cause toxicity and interfere with the effect of drugs. Limited knowledge on the interaction potential of medicinal plants poses a challenge and public health problem in Brazil and other countries.
\end{abstract}

\section{Introduction}

Medicinal plants are widely used in the treatment of several diseases, as cosmetics, pharmaceuticals, and chemicals [1]. Medicinal plants are popular because of their low financial cost and easy access to purchase without a prescription. The use of medicinal plants and phytonutrients or nutraceuticals has increased rapidly worldwide in recent years [2]. In Brazil, the use of medicinal plants has been embraced as complementary and alternative medicines $[3,4]$, as well as in the UK and the rest of Europe, North America, and Australia [5]. Except for India, Bulgaria, and Nepal, few countries have medicinal plant quality and control regulations [6]. The legislation on herbal medicines was revised to prepare new Brazilian standards [7]; 
however, the permissible limit of heavy metal concentration in medicinal plants is not yet established.

Environmental factors that affect plant growth and development include soil, temperature, water, humidity, and pollution [8]. However, effects of some organic compounds and their products present in medicinal plants on human health are not well known. Therefore, controlling heavy metal concentrations in both medicinal plants and their decoctions or infusions should be made to ensure the safety and effectiveness of herbal products [9].

The quality of medicinal plants regarding their nutritional value and toxicity can be evaluated by the determination of macro- and microelements. Element levels of Co, $\mathrm{Cr}, \mathrm{Cu}, \mathrm{Fe}, \mathrm{Mn}, \mathrm{Mo}$, Se, $\mathrm{Zn}$ etc. are necessary for the proper functioning of a living organism. However, excessive metal levels can be damaging to the organism $[10,11]$. The determination of the element levels of $\mathrm{As}, \mathrm{Cd}$, and $\mathrm{Pb}$ are essential because of their toxic nature and metabolic role [12].

To date, in Brazil, medicinal plants are freely sold on the open-air markets, at fairs, and especially by herbal vendors in the streets with little or no restriction [13]. Based solely on traditional knowledge, the herb sellers or companies marketing medicinal plants do not provide information on the maximum daily dosage that can cause toxicity in children, adults, and the elderly [14]. According to a study not published by a Brazilian research group (Spectroscopy and Bioinformatics Applied to Biodiversity and Health Group, Faculty of Medicine, Brazil), the labeling of the packaging (or plastic containers) of several marketed medicinal plants has similar dosages, i.e., the preparation consists of 2 or 3 tbsp added to one liter of water (decoction process). Also, there is no maximum daily dose per weight or age.

A freely traded medicinal plant is Cordia salicifolia Cham. or Cordia ecalyculata Vell. (Boraginaceae family). In Brazilian folk medicine, C. salicifolia is used as antiobesity medicine, appetite suppressant, and diuretic [13]. C. salicifolia is popularly known as "porangaba" or "cafezinho-domato" grows abundantly in the central and northeast regions of Brazil and the tropical forest areas of Argentina and Paraguay [15]. Another free-trade medicinal plant is Chiococca alba (L.) Hitchc.; its roots are used as diuretic, purgative, and snake bite medicine and are hydroponic [16]. C. alba (L.) Hitchc. (Rubiaceae), commonly known in Brazil as "Cainca" or "cipó-cruz," is a tropical and subtropical shrub distributed in some regions of Brazil [17]. Also, Echites peltata is a medicinal plant marketed freely in various regions of Brazil. It is used as an anti-inflammatory and indicated for chronic ulcers, diuretic, orchitis to combat uterine cramps, and rheumatic and joint pain. It is a climbing plant with alternating leaves and large clustered flowers. Its roots have a thick and bitter bark that froths when struck with water [18], popularly called the root of Joao da Costa or Erva Santa in Brazil.

Although some medicinal plants are used as supplements, foods, and teas to assist in weight control [19], information about their mineral composition is scarce. To date, metal levels in plant species including $C$. salicifolia, $C$. alba (L.) Hitchc., and E. peltata and their decoction have never been assessed. This work aimed to determine the content of $\mathrm{Cd}, \mathrm{Co}, \mathrm{Cr}, \mathrm{Cu}, \mathrm{Fe}, \mathrm{Na}, \mathrm{Pb}$, and $\mathrm{Zn}$ in these three different medicinal plant species C. salicifolia, C. alba (L.) Hitchc., and E. peltata, including their dry samples and decoctions, using the high-performance technique "inductively coupled plasma-optical emission spectrometry (ICP OES)." Metal contents detected in the dry plant samples were evaluated and compared with the permitted limits of metal impurities established by the United States Pharmacopoeia Convention (USP) ( $\mu \mathrm{g} / \mathrm{g}$ ) [20]. Besides, the metal content in these plant decoctions were compared with the oral permissible daily exposures established by the United States Pharmacopoeia Convention (USP) (mg/day) [20]. To the best of our knowledge, there are no scientific reports available on the human health risk assessment of some metals in these plants. Thus, $\mathrm{Cd}, \mathrm{Co}, \mathrm{Cr}, \mathrm{Cu}, \mathrm{Fe}, \mathrm{Na}, \mathrm{Pb}$, and $\mathrm{Zn}$ were assessed by evaluating the chronic daily intake (CDI) and hazard quotient (HQ) to determine the hazard indices (HI) in the decoctions prepared by mixing the plant samples in water [21].

\section{Materials and Methods}

2.1. Samples. A total of 30 samples of various commercially available medicinal plants were randomly purchased from "Cha \& Cia Produtos Naturais" in Brazil during the period of 2018-2019. The plant samples were commercially available in the plastic containers with pieces of leaves (C. salicifolia), wood (C. alba (L.) Hitchc.), and branches (E. peltata); each plastic container contains $100 \mathrm{~g}$ of the herbs raw material.

\subsection{Sample Preparation by Microwave Digestion}

2.2.1. Microwave Digestion for Dry Plant Samples. For the analysis of the leaves (C. salicifolia), wood (C. alba (L.) Hitchc. (Cainca)), and branches (E. peltata), samples of each plant were subjected to a drying process for 6 hours in a hot oven at $45^{\circ} \mathrm{C}$. Immediately after drying, accurately weighed $100 \mathrm{~g}$ of each sample was crushed and sieved (stainless steel sieve, $200 \mu \mathrm{m}$ granulometry). In the procedure, each sample of the plant $(0.25 \mathrm{~g})$ was weighed into the digestion vessels. 0.1 to $0.5 \mathrm{~g}$ of the sample, which is the recommended weight by the Brazilian Pharmacopoeia, was used in our experiment [22]. The digestion was performed by adding $3.0 \mathrm{~mL}$ of $\mathrm{HNO}_{3}$ (65\%; Merck), $1.0 \mathrm{~mL}$ of high-purity water (18 M $\Omega \cdot \mathrm{cm}$; Milli-Q, Millipore, Bedford, MA, USA), and $2.0 \mathrm{~mL}$ of $\mathrm{H}_{2} \mathrm{O}_{2}$ (35\%; Merck) to the sample. All vessels with the samples of plants were placed in the microwave digestion system (Speedwave 4-Microwave Digestion System; BERGHOF Products + Instruments $\mathrm{GmbH}$ ), according to the digestion program instruction depicted in Table $1[23,24]$. The microwave oven heating program was carried out in three steps.

2.2.2. Microwave Digestion for Plant Teas. Recent methodology of microwave digestion for plant teas is given in Ref. $[23,24]$. As an experimental quality control to the methodologies, each tablespoon corresponds to $10 \mathrm{~g}$ of the 
TABLE 1: Heating program for microwave digestion of dry plant samples.

\begin{tabular}{lccccc}
\hline Step & Temperature $\left({ }^{\circ} \mathrm{C}\right)$ & Pressure $($ bar $)$ & $T_{\text {Ramp }}(\mathrm{min})$ & $T_{\text {Hold }}(\mathrm{min})$ & 5 \\
1 & 160 & 35 & 1 & 10 & 1120 \\
2 & 190 & 35 & 1 & 1 & 10 \\
3 & 50 & 0 & 1 & 0 \\
\hline
\end{tabular}

powder sample. In the labeling of the plastic packaging of medicinal plants sold by companies, the decoction process happens by adding 2 or 3 tablespoons in a liter of water. However, in our experiment, we consider 1, 2, and 4 tablespoons in a liter of water. We filled three glass beakers (total capacity $2000 \mathrm{~mL}$ ) with $1000 \mathrm{~mL}$ of high-purity water, and then $10 \mathrm{~g}, 20 \mathrm{~g}$, and $40 \mathrm{~g}$ of each plant sample were added, respectively. The samples were covered and boiled by using a heating plate for $10 \mathrm{~min}$. Next, the samples were covered and left at room temperature of $25 \mathrm{~min}$.

After cooling, the extract was filtered through a quantitative filter paper. After this, in each of the tea samples was added aliquots of $1 \mathrm{~mL}$ of concentrated $\mathrm{HNO}_{3}$ (65\%; Merck) and $0.5 \mathrm{~mL}$ of $\mathrm{H}_{2} \mathrm{O}_{2}$ (35\%; Merck). All analyses were carried out in triplicate, and analytical blanks were also prepared following the same procedure used for the samples. Subsequently, the tea samples were placed in the digestion vessels of microwave digestion system (Speedwave 4-Microwave Digestion System; BERGHOF Products + Instruments $\mathrm{GmbH}$ ), according to the operating program specified in Table 2. The final volume was adjusted to $10 \mathrm{~mL}$ with ultrapure water (Milli-Q Biocel Water Purification System; Millipore, Germany).

2.3. Calibration Procedure. The calibration curves and stock solution to mineral detection were set up with high-purity water and nitric acid. The concentrations of the different elements in these samples were measured using the corresponding multielement standard solution $(100 \mathrm{mg} / \mathrm{L}$; Specsol, São Paulo, Brazil) containing $\mathrm{Co}, \mathrm{Cu}, \mathrm{Fe}, \mathrm{Na}$, and $\mathrm{Zn}$ and monoelement standard solution $(100 \mathrm{mg} / \mathrm{L}$, Specsol, São Paulo, Brazil) containing $\mathrm{Ca}, \mathrm{Cr}$, and $\mathrm{Pb}$. A nine-point calibration curve was generated using the following concentrations: $0.01,0.025,0.05,0.1,0.25,0.5,1.0,2.0$, and $4.0 \mathrm{ppm}$ of the element standards.

2.4. Elemental Analysis by ICP OES Technique. After microwave-assisted digestion with a mixture of nitric acid and hydrogen peroxide, a clear solution was obtained and the analytes were determined by ICP OES (iCAP 6300 Duo; Thermo Fisher Scientific, Bremen, Germany). Table 3 shows the instrumental conditions maintained for the analysis of $\mathrm{Cd}, \mathrm{Co}, \mathrm{Cr}, \mathrm{Cu}, \mathrm{Fe}, \mathrm{Na}, \mathrm{Pb}$, and $\mathrm{Zn}$. Parameters of the analytical curve for all studied elements are presented in Table 4.

Regarding validation, the detection limit (LOD) was calculated as three times the standard deviation of the blank expressed in concentration divided by slope of the analytical curve, and the limit of quantification (LOQ) was obtained ten times the standard deviation of the blank divided by slope of the analytical curve according to IUPAC [25]. The
TABle 2: Heating program for microwave digestion of by tea.

\begin{tabular}{lccccc}
\hline Step & $\begin{array}{c}\text { Temperature } \\
\left({ }^{\circ} \mathrm{C}\right)\end{array}$ & $\begin{array}{c}\text { Pressure } \\
(\text { bar })\end{array}$ & $\begin{array}{c}T_{\text {Ramp }} \\
(\mathrm{min})\end{array}$ & $\begin{array}{c}T_{\text {Hold }} \\
(\mathrm{min})\end{array}$ & $\begin{array}{c}\text { Power } \\
(\mathrm{W})\end{array}$ \\
\hline 1 & 100 & 30 & 1 & 5 & 840 \\
2 & 150 & 30 & 1 & 10 & 1120 \\
3 & 50 & 25 & 1 & 1 & 0 \\
\hline
\end{tabular}

TABLE 3: ICP OES instrumental parameters.

\begin{tabular}{lc}
\hline Parameters & ICP OES \\
\hline Radiofrequency power & $1150 \mathrm{~W}$ \\
Pump flow & $50 \mathrm{rpm}$ \\
Plasma argon flow & $12.00 \mathrm{~L} \mathrm{~min}^{-1}$ \\
Auxiliary argon flow & $0.50 \mathrm{~L} \mathrm{~min}^{-1}$ \\
Nebulizer gas flow & $0.70 \mathrm{~L} \mathrm{~min}^{-1}$ \\
Plasma view & Axial \\
Analytes & Wavelength $(\mathrm{nm})$ \\
$\mathrm{Cd}$ & 228.8 \\
$\mathrm{Co}$ & 228.6 \\
$\mathrm{Cr}$ & 283.5 \\
$\mathrm{Cu}$ & 324.7 \\
$\mathrm{Fe}$ & 259.9 \\
$\mathrm{Na}$ & 588.9 \\
$\mathrm{~Pb}$ & 220.3 \\
$\mathrm{Zn}$ & 213.8 \\
\hline
\end{tabular}

TABLE 4: Calibration equations (equations $(A=\mathrm{aC}+\mathrm{I})^{*}$, correlation coefficients, LOD, and LOQ obtained by external calibration).

\begin{tabular}{lcccc}
\hline Analyte & $\begin{array}{c}\text { External calibration } \\
\text { equation }\end{array}$ & $R^{2}$ & LOD $(\mu \mathrm{g} / \mathrm{L})$ & LOQ $(\mu \mathrm{g} / \mathrm{L})$ \\
\hline $\mathrm{Cd}$ & $A=18394 \mathrm{C}+140$ & 0.9999 & 0.2 & 0.7 \\
$\mathrm{Co}$ & $A=6790 \mathrm{C}+70$ & 0.9999 & 0.5 & 1.7 \\
$\mathrm{Cr}$ & $A=18636 \mathrm{C}+92$ & 0.9999 & 0.3 & 1.1 \\
$\mathrm{Cu}$ & $A=31716 \mathrm{C}+273$ & 0.9999 & 0.4 & 1.3 \\
$\mathrm{Fe}$ & $A=11560 \mathrm{C}+149$ & 0.9997 & 0.8 & 2.5 \\
$\mathrm{Na}$ & $A=377454$ & 0.9997 & 0.9 & 3 \\
$\mathrm{~Pb}$ & $\mathrm{C}-4767$ & 0.9998 & 2.2 & 7.4 \\
$\mathrm{Zn}$ & $A=947 \mathrm{C}+11$ & 1.2 & 4.2 \\
\hline$*$ & $A=11563 \mathrm{C}+183$ & 0.9996 & 1.2 & \\
\hline
\end{tabular}

external calibration equation and their respective correlation coefficients $\left(R^{2}\right)$ are presented in Table 4 . The values of LOD were in the range of $0.2-2.3(\mu \mathrm{g} / \mathrm{L})$, and the values of LOQ were 0.7-7.7 $(\mu \mathrm{g} / \mathrm{L})$ as shown in Table 4.

2.5. Validation of Methods. The accuracy of the measurements was determined by a spike recovery test by adding $0.5 \mathrm{mg} / \mathrm{kg}$ and $1.0 \mathrm{mg} / \mathrm{kg}$ of each metal in dry plant samples. The results were obtained as the average of three replicates of 
TABLE 5: Validation of methods using the spike concentration of plant samples.

\begin{tabular}{lc}
\hline Analyte & Spike concentration (\%) \\
\hline $\mathrm{Cd}$ & $95-100$ \\
$\mathrm{Co}$ & $94-98$ \\
$\mathrm{Cr}$ & $100-04$ \\
$\mathrm{Cu}$ & $98-106$ \\
$\mathrm{Fe}$ & $95-105$ \\
$\mathrm{Na}$ & $108-127$ \\
$\mathrm{~Pb}$ & $91-95$ \\
$\mathrm{Zn}$ & $97-103$ \\
\hline
\end{tabular}

each sample and are shown in Table 5. As can be seen, the method has good accuracy and the recoveries were between $91 \%$ and $127 \%$.

2.6. Comparative Study. The commercialization of medicinal plants in Brazil occurs in the form of tablets, capsules, powders, teas, extracts, and fresh or dried plants. Thus, the metal contents quantified in the dry plant samples $(\mu \mathrm{g} / \mathrm{g})$ were compared with oral concentration obtained from the permitted concentration of elemental impurities in drug substances and excipients established by the United States Pharmacopoeia Convention (USP) [20]. Also, the metal concentration detected in the decoction processes of the plants $(\mu \mathrm{g} / \mathrm{L})$ was evaluated and compared with the oral permitted daily exposures (EDPs) by the United States Pharmacopoeia Convention [20].

Acceptable levels of impurities for components (drug substances and excipients) in drug products are established by the United States Pharmacopoeia Convention (USP). USP considers oral permitted daily exposures (EDPs) based on the amount of elemental impurities in medicinal products. Elemental impurities include catalysts and environmental contaminants that may be present in drug substances, excipients, or drug products [20].

2.7. Estimation of Human Health Risk Assessment. Based on the above information, a risk-based control strategy is appropriate to ensure compliance with this standard. Thus for the risk assessment, the presence of elements such as cadmium $(\mathrm{Cd})$, cobalt $(\mathrm{Co})$, chromium $(\mathrm{Cr})$, copper $(\mathrm{Cu})$, iron $(\mathrm{Fe})$, sodium $(\mathrm{Na})$, lead $(\mathrm{Pb})$, and zinc $(\mathrm{Zn})$ in substances, excipients, or medications is considered.

In order to estimate human health risk associated with heavy metals in teas prepared from each medicinal plant in different concentrations (one tablespoons $=10 \mathrm{~g}$ of each sample, two tablespoons $=20$ grams of each sample, and four tablespoons $=40$ grams of each sample), chronic daily intake (CDI) was calculated first using the following equation [21]:

$$
\mathrm{CDI}=\frac{\mathrm{CP} \times \mathrm{IR} \times \mathrm{EF} \times \mathrm{ED}}{\mathrm{Bw} \times \mathrm{AT}},
$$

where CDI is the chronic daily intake by ingestion $(\mathrm{mg} / \mathrm{kg} /$ day) to which consumers might be exposed [21]. CP is the chemical concentration in a plant $(\mathrm{mg} / \mathrm{L})$; in this study, values obtained by ICP OES. IR is the ingestion rate (L/day)
[26]; in this study, $1 \mathrm{~L} /$ day for adults. EF is the exposure frequency (days/year); in this study, 90 days/year. ED is the exposure duration (years); in this study, 30 years for adults. Bw is the body weight $(\mathrm{kg})$; in this study, $70 \mathrm{~kg}$ for adults [27]. The AT is the averaging time for noncarcinogens (period over which the exposure is averaged (days)); in this study, $\mathrm{AT}=\mathrm{ED} \times 90$ days $=2700$ days [21].

Determination of accurate data from chronic daily intake (CDI) is complex, and it usually requires exposure frequency (180-350 days) and duration among individuals $(30,68.35$, and 70 years $)$, body weight $(60-70 \mathrm{~kg})$, ingestion rate of vegetables or liquids (1-2 L/day), and average time (exposure days within whole lifetime) [21].

2.7.1. Hazard Quotient (HQ). The risk of consumption of metal-contaminated medicinal plants in human health was characterized by hazard quotient (HQ), as shown in equation (2). HQ is the ratio of determined dose of a pollutant to the reference dose $(\mathrm{RfD})$. If $H Q>1$, the population will experience health risk, while $\mathrm{HQ}<1$ represents the acceptable level (population will pose no risk). An estimate of the potential hazard to human health (HQ) through consumption of medicinal plants grown in metal-contaminated soil is calculated in the following equation:

$$
\mathrm{HQ}=\frac{\mathrm{CDI}}{\mathrm{RfD}}
$$

where CDI is the chronic daily intake $(\mathrm{mg} / \mathrm{kg} /$ day) in each plant and different concentrations (equation (1)) and RfD is the chronic oral reference dose for the metal(loid)s ( $\mathrm{mg} / \mathrm{kg}$ of body weight per day) [28], which does not cause a lifetime deleterious effect.

2.7.2. Hazard Index (HI). The hazard index is the sum of the hazard quotients; it is calculated due to the presence of more than one heavy metal in the sample (equation (3)). USEPA developed the hazard index (HI) in 1989 [29]. That is, the hazard index assumes that the magnitude of the adverse effect will be proportional to the sum of several element exposures. In many studies, risk is assessed by assuming the sum of all elements quantified from a specific sample, in which chemical(s) concentration(s) have been measured by equipment such as inductively coupled plasma mass spectrometry (ICP MS) [30, 31] or inductively coupled plasmaoptical emission spectrometry (ICP OES) [32].

$$
\begin{aligned}
\mathrm{HI}= & \sum(\mathrm{HQ})=\mathrm{HQ}_{\mathrm{Cd}}+\mathrm{HQ}_{\mathrm{Co}}+\mathrm{HQ}_{\mathrm{Cr}}+\mathrm{HQ}_{\mathrm{Cu}}+\mathrm{HQ}_{\mathrm{Fe}} \\
& +\mathrm{HQ}_{\mathrm{Na}}+\mathrm{HQ}_{\mathrm{Pb}}+\mathrm{HQ}_{\mathrm{Zn}} .
\end{aligned}
$$

If $\sum(\mathrm{HQ})<1$, it is assumed that chronic risk is unlikely to occur due to tea ingestion of this plant.

2.8. Statistical Analysis. Results obtained were reported using the Origin 9.0 software (OriginLab Corporation, Northampton, MA, USA.). Concentrations were expressed as mean \pm standard deviation, minimum, and 
maximum values. One-way analysis of variance (ANOVA) was used to test for differences in element levels in the dry plant samples. The association between elements was examined using Person's correlation coefficient. Significant correlations were declared weak $(r<0.3)$, moderate $(r$ from 0.3 to 0.7$)$, or strong $(r>0.7)$. Results were considered significant if $p \leq 0.05$.

\section{Results and Discussion}

3.1. Dry Plant samples. As can be seen in Table 6, the concentration of the metals in the leaves of C. salicifolia in $\mu \mathrm{g} / \mathrm{g}$ decreases in the order of $\mathrm{Na}>\mathrm{Fe}>\mathrm{Zn}>\mathrm{Cu}>\mathrm{Pb}>\mathrm{Cr}>\mathrm{Cr}$, whereas in the wood of $C$. alba was in the order of $\mathrm{Fe}>\mathrm{Zn}>\mathrm{Na}>\mathrm{Cu}>\mathrm{Pb}>\mathrm{Cr}>\mathrm{Cd}$, and in the branches of $E$. peltata was $\mathrm{Fe}>\mathrm{Na}>\mathrm{Cu}>\mathrm{Zn}>\mathrm{Pb}>\mathrm{Cr}>\mathrm{Co}$.

According to the ANOVA statistical analysis, the highest concentration of metals is found in the leaves of C. salicifolia $(66.36 \pm 2.9)$, followed by the wood of C. alba $(37.83 \pm 1.21)$, and lastly in the branches of E. peltata $(33.05 \pm 1.10)$. There are differences between the concentrations of the metals found in plants. On the other hand, Table 7 presents Pearson's correlation coefficients for $\mathrm{Cd}, \mathrm{Co}, \mathrm{Cr}, \mathrm{Cu}, \mathrm{Fe}, \mathrm{Na}$, $\mathrm{Pb}$, and $\mathrm{Zn}$ in the samples of medicinal plants. The matrix shows the strength of the linear relationships between each pair of variables. In this study, a significant moderate and positive correlation was determined between $\mathrm{Zn}$ and $\mathrm{Cd}$ $(r=0.688), \mathrm{Pb}$ and $\mathrm{Cu}(r=0.58871), \mathrm{Pb}$ and $\mathrm{Fe}(r=0.4772)$, $\mathrm{Zn}$ and $\mathrm{Na}(r=0.3160)$, and $\mathrm{Cu}$ and $\mathrm{Cd}(r=0.3054)$. Furthermore, the correlation analysis showed a significant strong and positive correlation between $\mathrm{Na}$ and $\mathrm{Cd}$ $(r=0.9055), \mathrm{Fe}$ and $\mathrm{Co}(r=0.8905), \mathrm{Cu}$ and $\mathrm{Cr}(r=0.8049)$, $\mathrm{Pb}$ and $\mathrm{Cr}(r=0.9535)$, and $\mathrm{Zn}$ and $\mathrm{Cu}(r=0.9007)$ in the samples. There was a significant moderate and negative correlation between $\mathrm{Pb}$ and $\mathrm{Cd}(r=-0.5899), \mathrm{Cr}$ and $\mathrm{Cd}$ $(r=-0.3192), \mathrm{Na}$ and $\mathrm{Co}(r=-0.5026), \mathrm{Na}$ and $\mathrm{Cr}$ $(r=-0.6912), \mathrm{Fe}$ and $\mathrm{Cu}(r=-0.4295)$, and $\mathrm{Cu}$ and $\mathrm{Co}$ $(r=-0.7933)$. In addition, there was a significant strong and negative correlation between $\mathrm{Co}$ and $\mathrm{Cd}(r=-0.8220), \mathrm{Cr}$ and $\mathrm{Cd}(r=-0.3192), \mathrm{Fe}$ and $\mathrm{Cd}(r=-0.9911), \mathrm{Zn}$ and $\mathrm{Co}$ $(r=-0.9791), \mathrm{Na}$ and $\mathrm{Fe}(r=-0.8409)$, and $\mathrm{Pb}$ and $\mathrm{Na}$ $(r=-0.8769)$.

The content of Cd ranged between $0.7 \pm 0.1 \mu \mathrm{g} / \mathrm{g}$ in $E$. peltata branches and $0.3 \pm 0.06 \mu \mathrm{g} / \mathrm{g}$ in C. alba wood (Table 6). The content of Cd in E. peltata branches is below the limit of detection (Table 6). The permitted concentration of impurities such as Cd (oral concentration) set by the USP was $5.0 \mu \mathrm{g} / \mathrm{g}$ [33], and after comparison with other medicinal plants, it is found that the Cd content in the plants used in this study is below this limit [33].

The content of Co in C. salicifolia leaves and C. alba wood is below the limit of detection (Table 6). On the other hand, the amount of Co in the branches of E. peltata analyzed was $0.4 \pm 0.01 \mu \mathrm{g} / \mathrm{g}$. The permitted concentration of impurities such as Co established by the USP in drug substances and excipients was $5 \mu \mathrm{g} / \mathrm{g}$. Thus, Co concentration in the branches of E. peltata, obtained in the present study, was below the value established by USP [20].
The lowest content of $\mathrm{Cr}$ was in C. salicifolia leaves, that is, $0.9 \pm 0.1 \mu \mathrm{g} / \mathrm{g}$, and the maximum concentration of $1.3 \pm 0.1 \mu \mathrm{g} / \mathrm{g}$ was in C. alba wood and that of $1.0 \pm 0.03 \mu \mathrm{g} / \mathrm{g}$ was in branches of E. peltata (Table 6). Thus, the Cr content in these plant samples is below the permitted concentration of impurities for drug substances and excipients established by the USP $(1100 \mu \mathrm{g} / \mathrm{g})$ [20].

As shown in Table 6 , the range of $\mathrm{Cu}$ content varied between $9.5 \pm 0.8 \mu \mathrm{g} / \mathrm{g}$ in C. salicifolia leaves, $13 \pm 1.1 \mu \mathrm{g} / \mathrm{g}$ in C. alba wood, and $7.3 \pm 1.0 \mu \mathrm{g} / \mathrm{g}$ in branches of E. peltata. The $\mathrm{Cu}$ concentration in these plant samples was below the permitted concentration of impurities for drug substances and excipients set by the USP $(300 \mu \mathrm{g} / \mathrm{g})$.

The concentration of Fe in the leaves of C. salicifolia, the wood of $C$. alba, and the branches of E. peltata were $135 \pm 10 \mu \mathrm{g} / \mathrm{g}, 176 \pm 1.7 \mu \mathrm{g} / \mathrm{g}$, and $225 \pm 8.3 \mu \mathrm{g} / \mathrm{g}$, respectively (Table 6). There is no concentration limit of elemental impurities such as $\mathrm{Fe}$ in drug substances and excipients established by USP [20].

According to Table 6, the leaves of $C$. salicifolia has the highest $\mathrm{Na}$ content, that is, $135 \pm 10 \mu \mathrm{g} / \mathrm{g}, C$. alba wood $176 \pm 1.7 \mu \mathrm{g} / \mathrm{g}$ and E. peltata branches $225 \pm 8.3 \mu \mathrm{g} / \mathrm{g}$. However, the Na concentration limit in drug substances and excipients has not yet been set by the USP [20].

Table 6 shows that the concentration of $\mathrm{Pb}$ in the leaves of C. salicifolia was $1.8 \pm 0.2 \mu \mathrm{g} / \mathrm{g}, 1.4 \pm 0.005 \mu \mathrm{g} / \mathrm{g}$ for C. alba wood, and $3.6 \pm 0.02 \mu \mathrm{g} / \mathrm{g}$ for branches of $E$. peltata. The permitted concentration of $\mathrm{Pb}$ in drug substances and excipients established by the USP was $0.5 \mu \mathrm{g} / \mathrm{g}$ [20]. Thus, the $\mathrm{Pb}$ concentration in all these plants was above the permissible limit.

The concentration of Zinc element was much higher in the wood of C. alba, that is, $85 \pm 5.9 \mu \mathrm{g} / \mathrm{g}$, than in the leaves of C. salicifolia $68 \pm 8.0 \mu \mathrm{g} / \mathrm{g}$, followed by $5.7 \pm 0.2 \mu \mathrm{g} / \mathrm{g}$ in the branches of E. peltata (Table 6). The concentration limit of $\mathrm{Zn}$ in drug substances and excipients is not yet established by the USP [20].

3.2. Plant Teas. Table 8 shows the results of teas prepared by $10 \mathrm{~min}$ decoction obtained by mixing $10 \mathrm{~g}, 20 \mathrm{~g}$, and $40 \mathrm{~g}$ of the dried plant samples in glass beakers containing $1000 \mathrm{~mL}$ of water. The results obtained from the decoction process performed for the three plants and the respective amounts of tablespoons used to make the teas in $\mu \mathrm{g} / \mathrm{L}$ are presented in Table 8. In addition, the quantified metals in the plants were compared with the oral permitted daily exposure (EDP) values established by the USP ( $\mathrm{mg} /$ day) [20]. In comparison (Table 8), the levels of Cd and Co in some teas were low (below the detection limit).

In the decoction process performed by adding two tablespoons (10 g of each plant sample) in one liter of water (Table 8), the concentration of Cd in C. salicifolia leaves was $2.0 \pm 0.1 \mu \mathrm{g} / \mathrm{L}$, which was well below the value of permissible daily oral exposure (PDEs) established by the USP for Cd (5 $\mu \mathrm{g} /$ day). For four tablespoons ( $40 \mathrm{~g}$ ), the Cd concentration found in the tea of C. salicifolia leaves was $15 \pm 0.1 \mu \mathrm{g} / \mathrm{L}$, and for the tea of $C$. alba wood, it was $7.6 \pm 0.1 \mu \mathrm{g} / \mathrm{L}$. After comparing the metal concentration in the teas of the plants 
TABLE 6: Comparison of quantified metals in the medicinal plants with the permitted limits of metal impurities established by the USP $(\mu \mathrm{g} / \mathrm{g})$.

\begin{tabular}{|c|c|c|c|c|}
\hline \multirow{2}{*}{ Metals } & \multicolumn{3}{|c|}{ Dry plant samples $(\mu \mathrm{g} / \mathrm{g} \pm \mathrm{SD})$} & \multirow{2}{*}{ Oral concentration $(\mu \mathrm{g} / \mathrm{g})$ USP } \\
\hline & Cordia salicifolia leaves & Chiococca alba (L.) Hitchc. wood & Echites peltata branches & \\
\hline $\mathrm{Cd}$ & $0.7 \pm 0.1$ & $0.3 \pm 0.06$ & $<\mathrm{LOD}$ & $5^{*}$ \\
\hline Co & $<\mathrm{LOD}$ & $<$ LOD & $0.4 \pm 0.01$ & 5 \\
\hline $\mathrm{Cr}$ & $0.9 \pm 0.1$ & $1.3 \pm 0.1$ & $1.0 \pm 0.03$ & 1100 \\
\hline $\mathrm{Cu}$ & $9.5 \pm 0.8$ & $13 \pm 1.1$ & $7.3 \pm 1.0$ & 300 \\
\hline $\mathrm{Fe}$ & $135 \pm 10$ & $176 \pm 1.7$ & $225 \pm 8.3$ & - \\
\hline $\mathrm{Na}$ & $315 \pm 16$ & $23 \pm 2.8$ & $22 \pm 1.3$ & - \\
\hline $\mathrm{Pb}$ & $1.8 \pm 0.2$ & $4.1 \pm 0.1$ & $3.0 \pm 0.02$ & 0.5 \\
\hline $\mathrm{Zn}$ & $68 \pm 8.0$ & $85 \pm 5.9$ & $5.7 \pm 0.2$ & - \\
\hline
\end{tabular}

$<$ LOD, analyte concentration was below the limit of detection. *New values for Cadmium established in Ref. [33].

Table 7: Pearson's correlation coefficients for $\mathrm{Cd}, \mathrm{Co}, \mathrm{Cr}, \mathrm{Cu}, \mathrm{Fe}, \mathrm{Na}, \mathrm{Pb}$, and $\mathrm{Zn}$ in the samples of the medicinal plants.

\begin{tabular}{lccccccc}
\hline & $\mathrm{Cd}$ & $\mathrm{Co}$ & $\mathrm{Cr}$ & $\mathrm{Cu}$ & $\mathrm{Fe}$ & $\mathrm{Na}$ & $\mathrm{Pb}$ \\
\hline $\mathrm{Cd}$ & 1 & & & & & & \\
$\mathrm{Co}$ & -0.8220 & 1 & -0.2774 & 1 & & & \\
$\mathrm{Cr}$ & -0.3192 & -0.7933 & 0.8049 & 1 & & & \\
$\mathrm{Cu}$ & 0.3054 & 0.8905 & 0.1901 & -0.4295 & 1 & & \\
$\mathrm{Fe}$ & -0.9911 & -0.5026 & -0.6912 & -0.1276 & -0.8409 & 1 & \\
$\mathrm{Na}$ & 0.9055 & 0.0251 & 0.9535 & 0.5887 & 0.4772 & -0.8769 & 1 \\
$\mathrm{~Pb}$ & -0.5899 & -0.9791 & 0.4671 & 0.9007 & -0.7792 & 0.3160 & 0.1790 \\
$\mathrm{Zn}$ & 0.6888 & & & & & \\
\hline
\end{tabular}

TABLE 8: Metal concentration in the plant samples compared with the oral permissible daily exposures established by the USP (mg/day).

\begin{tabular}{|c|c|c|c|c|c|c|c|c|c|c|}
\hline \multirow[t]{2}{*}{ Analyte } & \multicolumn{3}{|c|}{$\begin{array}{l}\text { Tea with one tablespoon }(10 \mathrm{~g}) \\
(\mu \mathrm{g} / \mathrm{L} \pm \mathrm{SD})\end{array}$} & \multicolumn{3}{|c|}{$\begin{array}{l}\text { Tea with two tablespoons }(20 \mathrm{~g}) \\
(\mu \mathrm{g} / \mathrm{L} \pm \mathrm{SD})\end{array}$} & \multicolumn{3}{|c|}{$\begin{array}{l}\text { Tea with four tablespoons }(40 \mathrm{~g}) \\
\qquad(\mu \mathrm{g} / \mathrm{L} \pm \mathrm{SD})\end{array}$} & \multirow[t]{2}{*}{ Oral PDE ( $\mu \mathrm{g} /$ day $),$ USP } \\
\hline & Plant 1 & Plant 2 & Plant 3 & Plant 1 & Plant 2 & Plant 3 & Plant 1 & Plant 2 & Plant 3 & \\
\hline $\mathrm{Cd}$ & $<\mathrm{LOD}$ & IOP & SIOD & $2.0 \pm 0.1$ & IOD & I & $15+01$ & $7.6 \pm 0.1$ & $<\mathrm{LOD}$ & 5 \\
\hline Co & $<\mathrm{LOD}$ & & & & & & & & 2.9 & 50 \\
\hline $\mathrm{Cr}$ & $0.7 \pm 0.4$ & $2.9 \pm 0.7$ & $<\mathrm{LOD}$ & $4.6 \pm 0.2$ & $9.8 \pm 0.7$ & $3.6 \pm 0.9$ & $14 \pm 0.3$ & $23 \pm 0.3$ & 9.4 & 11000 \\
\hline $\mathrm{Cu}$ & $75 \pm 0.5$ & $95 \pm 1.2$ & $33 \pm 0.4$ & $143 \pm 0.04$ & $176 \pm 1.0$ & $81 \pm 0.2$ & $294 \pm 0.3$ & $374 \pm 0.3$ & $180 \pm 0.8$ & 3000 \\
\hline $\mathrm{Fe}$ & $1376 \pm 10$ & $1492 \pm 30$ & $668 \pm 8.6$ & $2216 \pm 8.4$ & $2473 \pm 4.1$ & $1379 \pm 4.2$ & $4851 \pm 11$ & $4876 \pm 13$ & $2524 \pm 11$ & - \\
\hline $\mathrm{Na}$ & $5525 \pm 53$ & $1745 \pm 30$ & $781 \pm 8.2$ & $9432 \pm 28$ & $2461 \pm 45$ & $668 \pm 6.2$ & $17404 \pm 43$ & $2385 \pm 21$ & $1151 \pm 4.6$ & - \\
\hline $\mathrm{Pb}$ & $13 \pm 0.7$ & $33 \pm 1.5$ & $9.2 \pm 1.1$ & $33 \pm 0.3$ & $83 \pm 0.7$ & $31 \pm 1.2$ & $75 \pm 1.3$ & $151 \pm 0.5$ & $68 \pm 1.2$ & 5 \\
\hline $\mathrm{Zn}$ & $577 \pm 5.3$ & $580 \pm 6.9$ & $<\mathrm{LOD}$ & $1065 \pm 1.4$ & $1114 \pm 2.5$ & $36 \pm 0.3$ & $2324 \pm 6.8$ & $2405 \pm 4.3$ & $124 \pm 11$ & - \\
\hline
\end{tabular}

$<$ LOD, analyte concentrations were below the limits of detection; SD, standard deviation. Plant 1: Cordia salicifolia leaves; Plant 2: Chiococca alba wood; Plant 3: Echites peltata branches.

( $40 \mathrm{~g}$ ) with those proposed by the USP, it is found that $C$. salicifolia and C. alba had $\mathrm{Cd}$ above the permissible oral daily exposure value [20].

The concentration of Co in the decoction process performed by adding four tablespoons $(40 \mathrm{~g})$ of branches of $E$. peltata was $2.9 \pm 0.2 \mu \mathrm{g} / \mathrm{L}$ (Table 8 ). The daily oral intake limit set by the USP for Co was $50 \mathrm{mg} / \mathrm{day}$, and the Co concentration in the E. peltata branches was below this limit [20].

In this study, $\mathrm{Cr}$ concentration from the plants in the decoction process varied between $0.7 \pm 0.4$ and $23 \pm 0.3 \mu \mathrm{g} / \mathrm{L}$ (Table 8 ), and the permissible oral daily exposure (PDE) value set by USP is $11,000 \mu \mathrm{g} /$ day [17]. On the other hand, the concentration of $\mathrm{Cu}$ from the plants varies widely between $33 \pm 0.4$ and $374 \pm 0.3 \mu \mathrm{g} / \mathrm{L}$, and the recommended PDE by the USP is $3000 \mu \mathrm{g} /$ day. In C. salicifolia leaves, C. alba wood, and E. peltata branches studied, the concentration of $\mathrm{Cr}$ and $\mathrm{Cu}$ is much lower than the permissible levels.
As shown in Table 8, the concentration of Fe in teas ranges between $668 \pm 8.6 \mu \mathrm{g} / \mathrm{L}$ and $4876 \pm 13 \mu \mathrm{g} / \mathrm{L}$ in all parts of the plants. There is no permissible oral daily exposure limit for Fe set by the USP. However, the maximum allowed concentration of $\mathrm{Fe}$ in drinking water is $1000 \mu \mathrm{g} / \mathrm{L}$, according to the WHO report [34]. After comparing the concentration of $\mathrm{Fe}$ in the plants with those proposed by the WHO, we found that only E. peltata branches (1 tablespoon $=10 \mathrm{~g}$ ) had Fe content below this limit, while all other plants had Fe content above this limit. To date, there is no iron poisoning found in humans due to the intake of iron-rich plants.

However, iron poisoning can be caused by taking high doses of iron supplements (pediatric patients) for prolonged periods or by taking a single overdose [35].

The concentration of $\mathrm{Na}$ in teas of plant samples varied from $668 \pm 6.2$ to $7404 \pm 43 \mu \mathrm{g} / \mathrm{L}$ (Table 8 ). The permissible 
oral daily exposure (PDEs) by the USP for $\mathrm{Na}$ has not yet been established. There is no agreement on the minimum daily requirement, and these recommendations have been controversial. However, a high level of sodium in drinking water seriously aggravates chronic congestive heart failure [36]. The concentration of $\mathrm{Na}$ is highest in human's and cow's milk, that is, 0.180 and $0.770 \mu \mathrm{g} / \mathrm{L}$ [37], respectively. The WHO suggests consuming $2 \mu \mathrm{g}$ of sodium per day [38]. After comparing the metal limit in the studied medicinal plants with those proposed by the WHO, it is found that all parts of the plants had $\mathrm{Na}$ above this limit.

The level of $\mathrm{Pb}$ in teas of plants varied from $9.2 \pm 1.1$ to $151 \pm 0.5 \mu \mathrm{g} / \mathrm{L}$ (Table 8 ). The permissible value (PDE) proposed by USP is $5 \mu \mathrm{g} /$ day, and the concentration values were all above the recommended value [20]. Lead is classified as a carcinogen by the Agency for Toxic Substances and Disease Registry (ATSDR) [39]. Besides, according to the recommendation of the Joint FAO/WHO Expert Committee on Food Additives, the weekly intake of lead should not exceed $25 \mu \mathrm{g} / \mathrm{kg}$ of body weight per week for humans [40, 41]. Based on such cited evidence [40,41], prolonged ingestion or large daily doses of tea from these plant types can cause toxicity due to the high accumulation of $\mathrm{Pb}$.

The concentration of $\mathrm{Zn}$ in the teas of these plants ranged from $36 \pm 0.3$ to $2405 \pm 4.3 \mu \mathrm{g} / \mathrm{L}$ (Table 8 ). The permissible oral daily exposure of Zn by USP has not yet been established. The maximum permissible limit of zinc in water reported by the WHO is $5000 \mu \mathrm{g} / \mathrm{L}$ [42]. In our study, the concentration of zinc is lower than the maximum permissible limit. On the other hand, according to the Agency for Toxic Substances and Disease Registry (ATSDR), the levels of zinc that produce adverse health effects are much higher than the recommended dietary allowance (RDAs) for zinc of $8-11 \mathrm{mg} /$ day for adults. Thus, the ingestion of large amounts of zinc into the body through food and water can also affect health [43].

3.3. Discussion on Human Health Risk Assessment. The chronic daily intake (CDI) and oral reference dose (RfD) of each heavy metal in plant teas are summarized in Table 9. The CDI values of $0.0000285 \mathrm{mg} / \mathrm{kg} / \mathrm{day}$ and $0.000214 \mathrm{mg} /$ $\mathrm{kg} /$ day for adults, respectively, were recorded for $\mathrm{Cd}$ in $C$. salicifolia leaves, while $0.000108 \mathrm{mg} / \mathrm{kg} /$ day was recorded for adults in C. alba wood. Also, the cadmium CDI values for adults were below the oral reference dose for Cd $(0.0005 \mathrm{mg} /$ $\mathrm{kg}$ /day). It is assumed that the consumption of the plant teas is $1 \mathrm{~L}$ per day. However, the consumption of more significant quantities of tea, four or more cups compared with 1 or less, may be detrimental to health. According to studies, cadmium induces cancers in animals and humans [44]. Cadmium toxicity affects photochemical and nutrient element composition of lettuce (Lactuca sativa L.) [45].

In Table 9, the CDI value of cobalt for adults $(0.00004142 \mathrm{mg} / \mathrm{kg} /$ day $)$ was below oral reference dose $(0.01 \mathrm{mg} / \mathrm{kg} / \mathrm{day})$. Toxicity caused by the ingestion of cobalt through food and water is rare. However, excessive exposure is related to the induction of various adverse health effects [46].
The CDI values of $\mathrm{Cr}$ for adults ranged within $0.00001-0.00021 \mathrm{mg} / \mathrm{kg} / \mathrm{day}$ in teas of $C$. salicifolia leaves, $0.0000414-0.000328 \mathrm{mg} / \mathrm{kg} /$ day in teas of C. alba wood, and $0.000051-0.000134 \mathrm{mg} / \mathrm{kg} / \mathrm{day}$ in teas of E. peltata branches. All CDI values are below oral reference dose $(0.0003 \mathrm{mg} / \mathrm{kg} /$ day), except for the teas of C. alba wood. $\mathrm{Cr}$ is an essential nutrient for humans, and foodstuffs (ingestion) generally contain extremely low chromium levels. Chromium (III) can be toxic if consumed in large doses [47].

The CDI values of $\mathrm{Cu}$ for adults in teas of $C$. salicifolia leaves $(0.00107-0.00420 \mathrm{mg} / \mathrm{kg} /$ day), teas of C. alba wood $(0.00135-0.005342 \mathrm{mg} / \mathrm{kg} / \mathrm{Day})$, and teas of E. peltata branches $(0.000471-0.002571 \mathrm{mg} / \mathrm{kg} /$ day $)$ are below the oral reference dose $(0.01 \mathrm{mg} / \mathrm{kg} /$ day). Copper plays a critical role in the biochemistry of all living organisms. However, $\mathrm{Cu}$ ingested in large amounts in the diet may cause toxicity [48].

The CDI values of $\mathrm{Fe}$ for adults ranged within $0.0196-0.0693 \mathrm{mg} / \mathrm{kg} / \mathrm{day}$ in teas of C. salicifolia leaves, $0.02131-0.0696 \mathrm{mg} / \mathrm{kg} /$ day in teas of $C$. alba wood, and $0.00954-0.0360 \mathrm{mg} / \mathrm{kg} /$ day in teas of E. peltata branches. All $\mathrm{CDI}$ values of $\mathrm{Fe}$ are above the oral reference dose $(0.007 \mathrm{mg} /$ $\mathrm{kg} /$ day). Iron is an essential trace element in living organisms. This element occurs as a natural constituent in plants. However, iron toxicity from intentional (suicide attempts) or accidental ingestion (potent adult preparations) is a common poisoning [49].

In Table 9, the CDI values of $\mathrm{Na}$ for adults varied in the range between 0.0789 and $0.24860 \mathrm{mg} / \mathrm{kg} /$ day in teas of $C$. salicifolia leaves, 0.0249 and $0.0351 \mathrm{mg} / \mathrm{kg} /$ day in teas of $C$. alba wood, and 0.0111 and $0.0351 \mathrm{mg} / \mathrm{kg} /$ day in teas of $E$. peltata branches. All CDI values of $\mathrm{Na}$ for adults are above the values of oral reference dose $(0.05 \mathrm{mg} / \mathrm{kg} /$ day $)$. Salt poisoning is an intoxication resulting from the excessive intake of sodium through diet. Fatal ingested sodium doses were estimated to be less than $25 \mathrm{~g}$ [50].

The CDI values of $\mathrm{Pb}$ for adults in teas of C. salicifolia leaves $(0.000185-0.00107 \mathrm{mg} / \mathrm{kg} /$ day) and teas of C. alba wood $(0.000471-0.002157 \mathrm{mg} / \mathrm{kg} /$ day $)$ were all below oral reference dose $(0.0035 \mathrm{mg} / \mathrm{kg} /$ day $)$, while that of in the tea of E. peltata branches $(0.000131-0.1265 \mathrm{mg} / \mathrm{kg} /$ day $)$ was above RfD values. Exposure to lead occurs via inhalation and ingestion of lead-contaminated food and water [51]. A high concentration of $\mathrm{Pb}$ can affect the central nervous, cardiovascular, and especially the immune systems [43]. Even the minimal presence of lead in the human body causes various health damages [52].

The CDI values of $\mathrm{Zn}$ for adults in the teas of C. salicifolia leaves, C. alba wood, and E. peltata branches varied from 0.00824 to $0.0332 \mathrm{mg} / \mathrm{kg} / \mathrm{day}, 0.00828$ to $0.0343 \mathrm{mg} / \mathrm{kg} / \mathrm{day}$, and $0.00051-0.001771 \mathrm{mg} / \mathrm{kg} / \mathrm{day}$, respectively. These CDI values of zinc for adults in the plant teas were below the oral reference dose $(0.3 \mathrm{mg} / \mathrm{kg} / \mathrm{day})$. Zinc is one crucial trace element in biological systems. The principal sources of exposure to zinc include the ingestion of food and drinking water [53]. Zinc poisoning can occur from dietary supplements by accident; ingestion of zinc greater than $150 \mathrm{mg}$ per day is toxic [54].

Table 10 contains the results of the analysis on hazard quotient (HQ) and total hazard index (HI) of the heavy 
TABLE 9: The chronic daily intake of heavy metals (CDI).

\begin{tabular}{|c|c|c|c|c|c|c|c|c|c|c|}
\hline \multirow[b]{2}{*}{ Analyte } & \multicolumn{3}{|c|}{ Tea with one tablespoon $(10 \mathrm{~g})$} & \multicolumn{3}{|c|}{ Tea with two tablespoons $(20 \mathrm{~g})$} & \multicolumn{3}{|c|}{ Tea with four tablespoons $(40 \mathrm{~g})$} & \multirow{2}{*}{$\begin{array}{l}\text { Oral reference dose } \\
\text { (RfD) for heavy } \\
\text { metals (mg/kg/day) }\end{array}$} \\
\hline & $\begin{array}{c}\text { Plant } 1 \\
\text { (CDI) }\end{array}$ & $\begin{array}{c}\text { Plant } 2 \\
\text { (CDI) }\end{array}$ & $\begin{array}{c}\text { Plant } 3 \\
\text { (CDI) }\end{array}$ & $\begin{array}{c}\text { Plant } 1 \\
\text { (CDI) }\end{array}$ & $\begin{array}{c}\text { Plant } 2 \\
\text { (CDI) }\end{array}$ & $\begin{array}{c}\text { Plant } 3 \\
\text { (CDI) }\end{array}$ & $\begin{array}{c}\text { Plant } 1 \\
\text { (CDI) }\end{array}$ & $\begin{array}{c}\text { Plant } 2 \\
\text { (CDI) }\end{array}$ & $\begin{array}{c}\text { Plant } 3 \\
(\mathrm{CDI})\end{array}$ & \\
\hline $\mathrm{Cd}$ & 0 & 0 & 0 & 0.0000285 & 0 & 0 & 0.000214 & 0.000108 & 0 & 0.0 \\
\hline Co & 0 & 0 & 0 & 0 & 0 & 0 & 0 & 0 & 0.0000414 & $1^{*}$ \\
\hline $\mathrm{Cr}$ & 0.00001 & 0.0000414 & 0 & 0.0000657 & 0.00014 & 0.000051 & 0.00021 & 0.000328 & 0.0 & $0.0003^{*}$ \\
\hline $\mathrm{Cu}$ & 0.00107 & 0.00135 & 0.000471 & 0.002042 & 0.002514 & 0.001157 & 0.00420 & 0.005342 & 0.002571 & $0.01^{*}$ \\
\hline $\mathrm{Fe}$ & 0.0196 & 002131 & 0.00954 & & & & & & 0.0360 & $0.007^{* *}$ \\
\hline $\mathrm{Na}$ & 0.0789 & 0.0249 & 0.0111 & 0.1347 & 0.0351 & 0.0351 & 0.2 & 0.0340 & 0.0164 & $0.05^{*}$ \\
\hline $\mathrm{Pb}$ & 0.000185 & 0.000471 & 0.000131 & 0.000471 & 0.00118 & 0.1265 & 0.00107 & 0.002157 & 0.000971 & $0.0035^{*}$ \\
\hline $\mathrm{Zn}$ & 0.00824 & 0.00828 & 0 & 0.0154 & 0.0154 & 0.00051 & 0.0332 & 0.0343 & 0.001771 & $0.3^{*}$ \\
\hline
\end{tabular}

*Source: ATSDR: Oral reference dose RfD for heavy metals (2019) [28]; ** source: USEPA IRIS (US Environmental Protection Agency) (2011) [21]. Plant 1: Cordia salicifolia leaves; Plant 2: Chiococca alba wood; Plant 3: Echites peltata branches.

TABLE 10: Hazard quotients (HQ) and total hazard index (HI) of the heavy metals.

\begin{tabular}{|c|c|c|c|c|c|c|c|c|c|}
\hline \multirow[b]{2}{*}{ Analyte } & \multicolumn{3}{|c|}{ Tea with one tablespoon $(10 \mathrm{~g})$} & \multicolumn{3}{|c|}{ Tea with two tablespoons $(20 \mathrm{~g})$} & \multicolumn{3}{|c|}{ Tea with four tablespoons ( $40 \mathrm{~g}$ ) } \\
\hline & $\begin{array}{c}\text { Plant } 1 \\
(\mathrm{HQ})\end{array}$ & $\begin{array}{c}\text { Plant } 2 \\
(\mathrm{HQ})\end{array}$ & $\begin{array}{c}\text { Plant } 3 \\
\text { (HQ) }\end{array}$ & $\begin{array}{c}\text { Plant } 1 \\
(\mathrm{HQ})\end{array}$ & $\begin{array}{c}\text { Plant } 2 \\
(\mathrm{HQ})\end{array}$ & $\begin{array}{c}\text { Plant } 3 \\
(\mathrm{HQ})\end{array}$ & $\begin{array}{c}\text { Plant } 1 \\
(\mathrm{HQ})\end{array}$ & $\begin{array}{c}\text { Plant } 2 \\
(\mathrm{HQ})\end{array}$ & $\begin{array}{c}\text { Plant } 3 \\
(\mathrm{HQ})\end{array}$ \\
\hline $\mathrm{Cd}$ & 0 & 0 & 0 & 0.05714 & 0 & 0 & 0.4285 & 0.21714 & 0 \\
\hline Co & 0 & 0 & 0 & 0 & 0 & 0 & 0 & 0 & 0.00414 \\
\hline $\mathrm{Cr}$ & 0.0333 & 0.1380 & 0 & 0.2190 & 0.4666 & 0.1740 & 0.6666 & 1.095 & 0.4476 \\
\hline $\mathrm{Cu}$ & 0.1071 & 0.1357 & 0.0471 & 0.2042 & 0.2514 & 0.1157 & 0.420 & 0.5342 & 0.2571 \\
\hline $\mathrm{Fe}$ & 2.8081 & 3.0448 & 1.3632 & 4.5224 & 5.0469 & 2.8142 & 9.90 & 9.9510 & 5.1510 \\
\hline $\mathrm{Na}$ & 1.5785 & 0.4985 & 0.2231 & 2.6948 & 0.7031 & 0.1908 & 4.9725 & 0.6814 & 0.3288 \\
\hline $\mathrm{Pb}$ & 0.0530 & 0.1346 & 0.0375 & 0.1346 & 0.3387 & 0.1265 & 0.3061 & 0.6163 & 0.2775 \\
\hline $\mathrm{Zn}$ & 0.0027 & 0.0276 & 0 & 0.0507 & 0.0530 & 0.0017 & 0.1106 & 0.1145 & 0.0059 \\
\hline HI & 4.5827 & 3.9792 & 1.6709 & 7.8257 & 6.8597 & 3.4229 & 16.432 & 13.420 & 6.420 \\
\hline
\end{tabular}

Plant 1: Cordia salicifolia leaves; Plant 2: Chiococca alba wood; Plant 3: Echites peltata branches.

metals for the human population ( $\mathrm{mg} / \mathrm{kg} / \mathrm{day})$. The HQ of $\mathrm{Cd}$ for adults was 0.05714 and 0.4285 in the teas of $C$. salicifolia leaves and 0.21714 in the teas of $C$. alba wood. The $\mathrm{HQ}$ values of $\mathrm{Cd}$ for adults in the teas of these plants were below 1.

The HQ for Co for adults is 0.00414 in E. peltata branch tea, which is less than 1 (Table 10). The HQ for Cr for adults varies from 0.0333 to 1.095 in the tea of the plants (Table 10). Only the HQ of $\mathrm{Cr}$ in C. alba wood was higher than 1 . The $\mathrm{HQ}$ value of $\mathrm{Cu}$ for adults in the teas of the plants varied widely between 0.0471 and 0.5342 (Table 10). All HQ values of $\mathrm{Cr}$ in the teas of the plants were over 1.

As shown in Table 10, the HQ value of Fe for adults in the teas of the plants range from 1.3632 to 9.951 , which is higher than 1.

As shown in Table 10, the HQ values of $\mathrm{Na}$ for adults in the teas of the plant samples varied from 0.1908 to 4.9725 . The HQ value of $\mathrm{Na}$ for adults in the teas of $C$. salicifolia leaves was 1.5785 (one tablespoon), 2.6948 for C. alba wood (two tablespoons), and 4.9725 for E. peltata branches (four tablespoons); all these values are above 1.

The HQ values of $\mathrm{Pb}$ for adults in the teas of the plant samples were in the range of 0.0375-0.6163 (Table 10). All values are greater than 1 .

The HQ o $\mathrm{Zn}$ for adults varied from 0.0017 to 0.1145 in the teas of the plants (Table 10), and thus the HQ values of $\mathrm{Zn}$ for adults were below the oral reference dose $(0.3 \mathrm{mg} / \mathrm{kg} /$ day).
In Table 10, the total hazard index (HI) of heavy metals is high for C. salicifolia leaves, followed by C. alba wood and branches of E. peltata. All the total hazard index (HI) values recorded in this study were above 1 .

Thus, the long-term health risk is high and the noncarcinogenic adverse effect is not negligible. The toxicity from medicinal plants depends on several factors, including the dose, route of exposure, and chemical species, as well as the age, gender, genetics, and nutritional status of the exposed individuals.

\section{Conclusions}

The concentrations of $\mathrm{Cd}, \mathrm{Co}, \mathrm{Cr}$, and $\mathrm{Cu}$ in the dry $C$. salicifolia leaves, C. alba wood, and E. peltata branches were below the oral concentration of elemental impurities established by the United States Pharmacopeia Convention (USP).

There is no concentration limit of elemental impurities such as $\mathrm{Fe}, \mathrm{Na}$, and $\mathrm{Zn}$ in drug substances and excipients established by the USP. All parts of plants had $\mathrm{Pb}$ at a concentration above the oral concentration of elemental impurities established by the United States Pharmacopoeia Convention (USP). Thus, taking the plant in capsules or tablets can be harmful to health.

The teas of $40 \mathrm{~g}$ C. salicifolia leaves and C. alba wood had $\mathrm{Cd}$ above the oral daily exposure value set by the USP. Other plants had $\mathrm{Co}, \mathrm{Cr}$, and $\mathrm{Cu}$ below the oral permitted daily 
exposure (EDP) values established by the USP (mg/day). The permissible oral daily exposures (PDEs) for $\mathrm{Fe}, \mathrm{Na}$, and $\mathrm{Zn}$ have not yet been set by the USP. The level of $\mathrm{Pb}$ in teas of plants was above the recommended value by the USP.

Concerning human health risk assessment calculus, the $\mathrm{CDI}$ values of $\mathrm{Cd}, \mathrm{Co}, \mathrm{Cr}, \mathrm{Cu}$, and $\mathrm{Zn}$ for adults in plant teas were all below the oral reference dose. On the other hand, the CDI values of $\mathrm{Cr}$ (tea with four tablespoons of C. alba), Fe, $\mathrm{Na}$, and $\mathrm{Pb}$ for adults were above the oral reference dose, which resulted in a hazard index above 1 . These data show that the ingestion of these plants in decoction form could be toxic for adults. Although there are uncertainties associated with the estimates of toxicity values such as the averaging time for noncarcinogens (AT) and exposure frequency (EF), long-term health risk and the noncarcinogenic adverse effect are not negligible.

Medicinal plants are not classified as drugs by the Brazil law. The ingestion of medicinal plants and their products requires strict control of the presence of heavy metals, the dosage labeling, contraindications, manufacturing techniques, and principally a list of all composition. Although medicinal plants are effective in treating some diseases, their continued and uncontrolled use is of concern in many countries, including Brazil.

\section{Data Availability}

The data used to support the findings of this study are available from the corresponding author upon request.

\section{Conflicts of Interest}

The authors declare no conflicts of interest.

\section{Acknowledgments}

This research was partially supported by the Brazilian Research Council (CNPq) (CNPq: Process No 311336/2017-5). This study was financed in part by the Coordenação de Aperfeiçoamento de Pessoal de Nível Superior-Brasil (CAPES)-Finance Code 001.

\section{References}

[1] J. B. Calixto, "The role of natural products in modern drug discovery," Anais da Academia Brasileira de Ciências, vol. 91, no. suppl 3, Article ID e20190105, 2019.

[2] WHO, WHO Guidelines on Safety Monitoring of Herbal Medicines in Pharmacovigilance Systems, World Health Organization, Geneva, Switzerland, 2004, https://apps.who.int/ medicinedocs/documents/s7148e/s7148e.pdf.

[3] BRASIL, Ministério Da Saúde, Portal Da Saúde: Programa Nacional De Plantas Medicinais e Fitoterápicos, http://bvsms. saude.gov.br/bvs/publicacoes/programa_nacional_plantas_ medicinais_fitoterapicos.pdf.

[4] BRASIL, Ministério Da Saúde: Plantas de interesse ao SUS, Portal Da Saúde, Brasília, http://bvsms.saude.gov.br/bvs/ publicacoes/fitoterapia_no_sus.pdf.

[5] Institute of Medicine (US) Committee on the Use of Complementary and Alternative Medicine by the American Public, Complementary and Alternative Medicine in the United States,
National Academies Press (US), Washington, DC, USA, 2005, https://www.ncbi.nlm.nih.gov/books/NBK83799/.

[6] Trade in Medicinal Plants, FAO (Food and Agriculture Organization of the United Nations). Technical Document Repository by Raw Materials, Tropical and Horticultural Products Service, Commodities and Trade Division, Economic and Social Department, http://www.fao.org/docrep/008/af285e/ af285e00.HTM, Food and Agriculture Organization (FAO) of the United Nations, Rome, Italy, 2019, http://www.fao.org/ docrep/008/af285e/af285e00.HTM.

[7] A. C. B. Carvalho, L. S. Ramalho, R. F. O. Marques, and J. P. S. Perfeito, "Regulation of herbal medicines in Brazil," Journal of Ethnopharmacology, vol. 158, no. 2, pp. 503-506, 2014.

[8] D. Haidu, D. Párkányi, R. I. Moldovan et al., "Elemental characterization of Romanian crop medicinal plants by neutron activation analysis," Journal of Analytical Methods in Chemistry, vol. 2017, Article ID 9748413, 12 pages, 2017.

[9] L. S. Rocha, D. G. Arakaki, D. Bogo et al., "Evaluation of level of essential elements and toxic metal in the medicinal plant hymenaea martiana hayne (jatobá) used by mid-west population of Brazil," The Scientific World Journal, vol. 2019, Article ID 4806068, 7 pages, 2019.

[10] R. Singh, N. Gautam, A. Mishra, and R. Gupta, "Heavy metals and living systems: an overview," Indian Journal of Pharmacology, vol. 43, no. 3, pp. 246-253, 2011.

[11] J. Chronopoulos, C. Haidouti, A. Chronopoulou-Sereli, and I. Massas, "Variations in plant and soil lead and cadmium content in urban parks in Athens, Greece," Science of the Total Environment, vol. 196, no. 1, pp. 91-98, 1997.

[12] A. Jan, M. Azam, K. Siddiqui, A. Ali, I. Choi, and Q. Haq, "Heavy metals and human health: mechanistic insight into toxicity and counter defense system of antioxidants," International Journal of Molecular Sciences, vol. 16, no. 12, pp. 29592-29630, 2015.

[13] J. Lanini, J. M. Duarte-Almeida, S. A. Nappo, and E. A. Carlini, "Are medicinal herbs safe? The opinion of plant vendors from Diadema (São Paulo, southeastern Brazil)," Revista Brasileira de Farmacognosia, vol. 22, no. 1, pp. 21-28, 2012.

[14] V. F. Veiga Junior, A. C. Pinto, and M. A. M. Maciel, "Plantas medicinais: cura segura?," Química Nova, vol. 28, no. 3, pp. 519-528, 2005.

[15] G. L. Cruz, Dicionário das Plantas úteis do Brasil, vol. 5, Bertrand, Rio de Janeiro, Brazil, 1995, https://www. estantevirtual.com.br/livros/g-l-cruz/dicionario-das-plantasuteis-do-brasil/3946064968.

[16] L. M. Ricardo, J. d. Paula-Souza, A. Andrade, and M. G. L. Brandão, "Plants from the Brazilian traditional medicine: species from the books of the polish physician piotr czerniewicz (pedro luiz napoleão chernoviz, 1812-1881)," Revista Brasileira de Farmacognosia, vol. 27, no. 3, pp. 388400, 2017.

[17] C. C. d. Castro, P. E. A. M. d. Oliveira, and R. M. d. M. Pimentel, "Reproductive biology of the herkogamous vine Chiococca alba (L.) Hitchc. (Rubiaceae) in the atlantic rain forest, SE Brazil," Revista Brasileira de Botânica, vol. 31, no. 2, pp. 317-321, 2008.

[18] M. G. L. Brandão, G. P. Cosenza, I. C. Cesar, C. A. Tagliati, and L. C. Marques, "Influence of the preparation method on the low efficacy of multi-herb commercial products: the example of João da Costa e Associações," Revista Brasileira de Farmacognosia, vol. 20, no. 2, pp. 250-255, 2010.

[19] M. Koithan and K. Niemeyer, "Using herbal remedies to maintain optimal weight," The Journal for Nurse Practitioners, vol. 6, no. 2, pp. 153-154, 2010. 
[20] USP, Official from December 1, 2017, Copyright (c) 2017 The United States Pharmacopeia Convention. All rights reserved.

[21] USEPA IRIS (US Environmental Protection Agency)'s Integrated Risk Information System (2011), Environmental Protection Agency Region I, Washington, DC, USA, 2019, http:// www.epa.gov/iris/.

[22] Agência Nacional de Vigilância Sanitária, Farmacopeia Brasileira, vol. 1, National Health Surveillance Agency, Brasília, Brazil, 5th edition, National Health Surveillance Agency, Brasília, Brazil, 2010, http://www.anvisa.gov.br.

[23] L. S. Rocha, D. A. Gonçalves, D. G. Arakaki et al., "Data on elemental composition of the medicinal plant Hymenaea martiana Hayne (Jatobá)," Data in Brief, vol. 19, pp. 959-964, 2018.

[24] P. F. S. Tschinkel, E. S. de Pádua Melo, Z. M. Dutra et al., "Data on ICP OES and emulsion stability of Bredemeyera floribunda root extract: medicinal plant used by the Brazilian rural population to treat snakebites," Data in Brief, vol. 24, Article ID 103940, 2019.

[25] G. L. Long and J. D. Winefordner, "Limit of detection A closer look at the IUPAC definition," Analytical Chemistry, vol. 55, no. 7, pp. 712a-724a, 1983.

[26] M. S. Qaiyum, M. S. Shaharudin, A. I. Syazwan, and A. Muhaimin, "Health risk assessment after exposure to aluminium in drinking water between two different villages," Journal of Water Resource and Protection, vol. 3, no. 4, pp. 268-274, 2011.

[27] O. C. Ekhator, N. A. Udowelle, S. Igbiri, R. N. Asomugha, Z. N. Igweze, and O. E. Orisakwe, "Safety Evaluation of Potential Toxic Metals Exposure from Street Foods Consumed in Mid-West Nigeria," Journal of Environmental and Public Health, vol. 2017, Article ID 8458057, 8 pages, 2017.

[28] Agency for Toxic Substances and Disease Registry (ATSDR), Toxicological Profile for Lead. (Draft for Public Comment), U.S. Department of Health and Human Services, Public Health Service, Atlanta, GA, USA, 2019, https://www.atsdr.cdc.gov/ ToxProfiles $/$ tp.asp? $\mathrm{id}=96 \& \mathrm{tid}=22$.

[29] US Environmental Protection Agency (US EPA), Risk Assessment Guidance for Superfund: Human Health Evaluation Manual (Part A): Interim Final, U.S. Environmental Protection Agency, Washington, DC, USA, 1989.

[30] N. Zheng, J. Liu, Q. Wang, and Z. Liang, "Health risk assessment of heavy metal exposure to street dust in the zinc smelting district, Northeast of China," Science of The Total Environment, vol. 408, no. 4, pp. 726-733, 2010.

[31] E. Brima, "Toxic elements in different medicinal plants and the impact on human health," International Journal of Environmental Research and Public Health, vol. 14, no. 10, p. 1209, 2017.

[32] K. S. Balkhair and M. A. Ashraf, "Microbial contamination of vegetable crop and soil profile in arid regions under controlled application of domestic wastewater," Saudi Journal of Biological Sciences, vol. 23, no. 1, pp. S83-S92, 2016.

[33] International Council for Harmonization of Technical Requirements for Pharmaceuticals for Human Use, Guideline for Elemental Impurities Q3D(R1), 2018.

[34] G. Patil and A. Irfan, "Heavy metal contamination assesment of Kanhargaon dam water near Chhindwara city," Acta Chimica and Pharmaceutica Indica, vol. 1, no. 1, pp. 7-9, 2011.

[35] T. P.-Y. Chang and C. Rangan, "Iron poisoning," Pediatric Emergency Care, vol. 27, no. 10, pp. 978-985, 2011.

[36] World Health Organization, WHO Working Group on Sodium, Chlorides, and Conductivity in Drinking-Water, World Health Organization. Regional Office for Europe, WHO
Working Group on Sodium, Chlorides and Conductivity in Drinking-Water and WHO Working Group on Sodium, Chlorides, and Conductivity in Drinking-Water (1978: Hague, Netherlands) Sodium, Chlorides, and Conductivity in DrinkingWater: Report on a WHO Working group, World Health Organization, Regional Office for Europe, Copenhagen, Denmark, 1979.

[37] K. Diem and C. Lentner, Documenta Geigy. Scientific Tables, Ciba-Geigy, Basel, Switzerland, 7th edition, 1970.

[38] World Health Organization, Guideline: Sodium Intake for Adults and Children, World Health Organization, Geneva, Switzerland, 2012, http://www.who.int.

[39] Agency for Toxic Substances and Disease Registry (ATSDR), Toxicological Profile for Lead, U.S. Department of Health and Human Services, Public Health Service, Atlanta, GA, USA, 2007, https://www.atsdr.cdc.gov/ToxProfiles/TP.asp? $\mathrm{id}=96 \& \mathrm{tid}=22$.

[40] World Health Organization, Evaluation of Certain Food Additives and Contaminants. Forty-First Report of the Joint FAO/WHO Expert Committee on Food Additives, (WHO Technical Report Series, No. 837), World Health Organization, Geneva, Switzerland, 1993.

[41] World Health Organization, Toxicological Evaluation of Certain Food Additives and Contaminants. Seventy-Third Report of the Joint FAO/WHO Expert Committee on Food Additives, Vol. 163, World Health Organization, Geneva, Switzerland, 2011.

[42] World Health Organization (WHO), Guidelines for DrinkingWater Quality, World Health Organization, Geneva, Switzerland, 2011, https://apublica.org/wp-content/uploads/2014/ 03/Guidelines-OMS-2011.pdf, 4th edition.

[43] Agency for Toxic Substances and Disease Registry (ATSDR), Toxicological Profile of Zinc, http://www.atsdr.cdc.gov/ toxprofiles/tp60.pdf, 2015.

[44] A. Buha, D. Wallace, V. Matovic et al., "Cadmium exposure as a putative risk factor for the development of pancreatic cancer: three different lines of evidence," BioMed Research International, vol. 2017, Article ID 1981837, 8 pages, 2017.

[45] S. A. Jibril, S. A. Hassan, C. F. Ishak, and P. E. Megat Wahab, "Cadmium toxicity affects phytochemicals and nutrient elements composition of lettuce (Lactuca sativa L.)," Advances in Agriculture, vol. 2017, Article ID 1236830, 7 pages, 2017.

[46] L. Leyssens, B. Vinck, C. Van Der Straeten, F. Wuyts, and L. Maes, "Cobalt toxicity in humans-A review of the potential sources and systemic health effects," Toxicology, vol. 387, pp. 43-56, 2017.

[47] Agency for toxic substances and disease Registry case studies in environmental medicine (CSEM), Chromium toxicity, U.S. Department of Health and Human Services Agency for Toxic Substances and Disease Registry Division of Toxicology and Environmental Medicine Environmental Medicine and Educational Services Branch, 2011.

[48] A. Hefnawy and H. khaiat, "The importance of copper and the effects of its deficiency and toxicity in animal health," International Journal of Livestock Research, vol. 5, no. 12, pp. 1-20, 2015.

[49] H. W. Yuen and W. Becker, "Iron toxicity," in StatPearls, StatPearls Publishing, Treasure Island, FL, USA, 2019, https:// www.ncbi.nlm.nih.gov/books/NBK459224/.

[50] N. Campbell and E. Train, "A systematic review of fatalities related to acute ingestion of salt. A need for warning labels?," Nutrients, vol. 9, no. 7, p. 648, 2017. 
[51] Agency for Toxic Substances and Disease Registry (ATSDR, Public Health Service, U.S. Department of Health and Human Services, Atlanta, GA, USA, 1999.

[52] L. H. Mason, J. P. Harp, and D. Y. Han, "Pb neurotoxicity: neuropsychological effects of lead toxicity," BioMed Research International, vol. 2014, Article ID 840547, 8 pages, 2014.

[53] Agency for Toxic Substances and Disease Registry (ATSDR), Toxicological Profile for Zinc, U.S. Department of Health and Human Services, Public Health Service, Atlanta, GA, USA, 2005, https://www.atsdr.cdc.gov/toxprofiles/tp60.pdf.

[54] M. R. Lewis and L. Kokan, "Zinc gluconate," Journal of Toxicology: Clinical Toxicology, vol. 36, no. 1-2, pp. 99-101, 1998. 